RESEARCH PAPER

\title{
Flying the smoky skies: secondhand smoke exposure of flight attendants
}

\section{J Repace}

See end of article for authors' affiliations

Correspondence to:

J Repace, MSc, Repace

Associates, Inc, 101 Felicia

Lane, Bowie, 20720, USA:

repace@comcast.net

\begin{abstract}
Objective: To assess the contribution of secondhand smoke (SHS) to aircraft cabin air pollution and flight attendants' SHS exposure relative to the general population.

Methods: Published air quality measurements, modelling studies, and dosimetry studies were reviewed, analysed, and generalised.

Results: Flight attendants reported suffering greatly from SHS pollution on aircraft. Both government and airline sponsored studies concluded that SHS created an air pollution problem in aircraft cabins, while tobacco industry sponsored studies yielding similar data concluded that ventilation controlled SHS, and that SHS pollution levels were low. Between the time that non-smoking sections were established on US carriers in 1973, and the two hour US smoking ban in 1988, commercial aircraft ventilation rates had declined three times as fast as smoking prevalence. The aircraft cabin provided the least volume and lowest ventilation rate per smoker of any social venue, including stand up bars and smoking lounges, and afforded an abnormal respiratory environment. Personal monitors showed liftle difference in SHS exposures between flight attendants assigned to smoking sections and those assigned to non-smoking sections of aircraft cabins.

Conclusions: In-flight air quality measurements in $\sim 250$ aircraft, generalised by models, indicate that when smoking was permitted aloft, $95 \%$ of the harmful respirable suspended particle (RSP) air pollution in the smoking sections and $85 \%$ of that in the non-smoking sections of aircraft cabins was caused by SHS. Typical levels of SHS-RSP on aircraft violated current $\left(\mathrm{PM}_{2.5}\right)$ federal air quality standards threefold for flight attendants, and exceeded SHS irritation thresholds by 10 to 100 times. From cotinine dosimetry, SHS exposure of typical flight attendants in aircraft cabins is estimated to have been $>6$-fold that of the average US worker and $\sim 14$-fold that of the average person. Thus, ventilation systems massively failed to control SHS air pollution in aircraft cabins. These results have implications for studies of the past and future health of flight attendants.
\end{abstract}

- light attendants have worked on aircraft since 1931. By 1985 there were 40000 flight attendants employed by US airlines, ${ }^{1}$ and by 2000, the number had increased to almost $116000 .^{2}$ For years, flight attendants reported health problems they attributed to their occupational exposures. Yet, as recently as the mid 1980s, little had been done to characterise either the quality of the air in airliner cabins or its possible health effects on cabin crew, and there were no federal standards governing secondhand smoke (SHS) exposure. $^{1}$ Smoking in the USA was unrestricted on commercial passenger aircraft until 1973, when the US Civil Aeronautics Board ( $\mathrm{CAB}$ ) imposed regulations to separate smoking passengers from non-smoking passengers by establishing non-smoking sections on the basis of numerous complaints from passengers. ${ }^{3}$ However, in 1986, the National Academy of Sciences recommended a ban on smoking on domestic flights, ${ }^{1}$ and contemporaneously, both the Surgeon General ${ }^{4}$ and the National Academy of Sciences ${ }^{5}$ concluded that SHS caused lung cancer.

Most published air quality studies of SHS on aircraft were conducted after 1987, and no further regulation took place until 1988, when a US Congressionally mandated smoking ban took effect on domestic airline flights scheduled for two hours or less. ${ }^{6}$ At that time, Northwest Airlines voluntarily banned smoking on all its North American flights. In 1989, mainly based on complaints by flight attendants, the US Congress imposed a broader smoking ban on all US domestic flights of six hours duration or less. ${ }^{6}$ Subsequently, many airlines voluntarily banned smoking on flights longer than six hours, and by 1999 , a reported $97 \%$ of flights to and from the US were smoke-free. ${ }^{7}$ However, as recently as 1998, some US airlines, including Northwest, continued to permit smoking on their US based international flights to the Orient. Flight attendants exposed on such flights often encountered smoking prevalence far higher than on other routes. ${ }^{8}$

Because of complaints about poor air quality on aircraft, especially about SHS, a number of studies have measured airborne contaminants in aircraft cabins. The major pollutant emitted by tobacco smoking is respirable suspended particles (RSP), which, while not unique to SHS, typically dwarfs indoor air concentrations from other sources of RSP, and therefore is often used as an atmospheric tracer for SHS. ${ }^{1}{ }^{10}$ Nicotine, although much less copiously emitted than RSP, is a unique atmospheric tracer for SHS, and its metabolite, cotinine, is the definitive biomarker for SHS dose. Air pollution concentrations from SHS on passenger aircraft are determined by the ratio of the smoker density (time averaged number of cigarettes smoked per unit volume) to the air

\footnotetext{
Abbreviations: ASHRAE, American Society of Heating, Refrigerating, and Air Conditioning Engineers; CAB, Civil Aeronautics Board; CDC Centers for Disease Control; FAA, Federal Aviation Administration; NAS, National Academy of Sciences; NCl, National Cancer Institute; RSP, respirable suspended particles; SHS, secondhand smoke; TSP, total suspended particles; VOC, volatile organic compounds
} 
exchange rate supplied by aircraft ventilation systems. ${ }^{9}$ SHS dose is determined by the product of the smoke concentration to which persons are exposed, their respiration rates during exposure, and the duration of their exposure.

This paper reviews RSP and nicotine measurements on $\sim 250$ passenger aircraft as variously studied by the government, the airlines, non-governmental organisations, and the tobacco industry, as well as one federal study of cotinine dosimetry in flight attendants, emphasising post-1985 studies. The results of three modelling studies are reviewed to generalise the RSP data. This work also examines how various groups interpreted their data in terms of SHS policy, and for the first time, compares flight attendants' SHS doses on aircraft to SHS doses of the general US population. Finally, flight attendants historic SHS exposure is interpreted in light of late 1990s federal air quality standards, and a 21 st century study of irritation from SHS.

\section{AIRCRAFT VENTILATION SYSTEMS}

The first flight attendants flew on unpressurised propeller aircraft on low altitude flights. In the mid-1940s, pressurisation systems were introduced, and unfiltered cabin air recirculation systems were adopted to augment cabin airflow. ${ }^{7}$ Pressurisation of aircraft cabins permitted operation at higher altitudes, which substantially reduced aircraft drag and hence propulsion fuel costs. ${ }^{11}$ In the 1950s, the first commercial passenger jets, the B-707 and DC-8, were introduced. In the mid-1970s, B-747s began flying polar routes. By the early 1980s the majority of new transport aircraft employed a combination of engine bleed (outside) air coupled with filtered recirculated air in order to conserve fuel. Today, about $50 \%$ of commercial passenger aircraft use recirculated air; however, as the energy cost of cooling hot engine bleed air for ventilation has increased, this has led to a significant decrease in the amount of outside air provided to the passenger cabin. ${ }^{7112}$ For example, while the DC-10's nominal air exchange rates range from 7 to 21 cubic feet per minute per passenger $\left(\mathrm{ft}^{3} /\right.$ min per passenger), reduced flow valves permitted reducing these flow rates to a half to two thirds of normal, and on some planes, shutting down one of three ventilation packs. ${ }^{1}$ This is also possible-and was done in practice-on wide body three pack models of Boeing aircraft, such as the B-747 and the B-767.12-14 About 62000 gallons of fuel could be saved annually for each $10 \mathrm{ft}^{3} / \mathrm{min}$ per passenger reduction in an aircraft's ventilation rate. ${ }^{1}$ This practice is believed to be widespread in the economically troubled airline industry. Until 1996, US Federal Aviation Administration (FAA) regulations provided only that the airliner cabin passenger compartment "must be suitably ventilated", 158 and since 1996, have provided only that passenger cabin ventilation systems be designed (not operated) to provide $0.55 \mathrm{lbs}$ of outside air per design occupant (equivalent to $10 \mathrm{ft}^{3} / \mathrm{min}$ per occupant at 8000 feet of cabin pressure and $22^{\circ} \mathrm{C}$ cabin temperature). ${ }^{58}$

In 1970, the typical passenger aircraft provided $15 \mathrm{ft}^{3} / \mathrm{min}$ (7 litres/s) or more of outside air per person, but by 1987, this had declined to where some new commercial aircraft provided barely $6 \mathrm{ft}^{3} / \mathrm{min}$ per person ( 2.8 litres/s per person) of outside air flow to their passenger cabins. ${ }^{11}$ Moreover, at the pilot's discretion, aircraft manufactured during the 1970s could reduce outside airflows to $10 \mathrm{ft}^{3} / \mathrm{min}$ per person, and outside air delivery rates have been reduced to as low as $2.1 \mathrm{ft}^{3} /$ min per person ( 1 litre/s per person), or $\sim 1 / 10$ of that for office workers. ${ }^{11}{ }^{16}$ For example, one study of ventilation rates on seven aircraft, model unidentified, but seating up to 101 passengers, found that on 45 flights of one hour or less, whenever the number of passengers exceeded 34, the ventilation failed to meet the manufacturers' recommendation of 5 litres/s per passenger. ${ }^{16}$ For aircraft with particulate air filtration, nominal filter efficiency (90-99.98\%) varies with airline policy; however, such efficiencies are not attained in practice. ${ }^{11}$ Gaseous SHS contaminants are not filtered. Thus, aircraft ventilation rates have declined by a third to half or more since 1970.

In addition to low per person air exchange rates, aircraft cabins have the smallest available airspace per person of any social venue, and occupants of a fully loaded aircraft typically have about $35-70 \mathrm{ft}^{3}\left(1-2 \mathrm{~m}^{3}\right)$ of available airspace per person, $<1 / 10$ th that of a typical office worker or a spectator in an auditorium. ${ }^{11}$ Moreover, aircraft cabins have an abnormal respiratory environment relative to most human habitats: they typically are pressurised to only $\sim 75 \%$ that at sea level, equivalent to an altitude of $8000 \mathrm{ft}(2440 \mathrm{~m})$; at such a pressure, there is a lower oxygen partial pressure than at sea level. ${ }^{11}{ }^{17}$ In addition, the upper limits on carbon dioxide concentrations in aircraft are five times higher than in buildings. ${ }^{12}$ The combination of lower partial pressure of oxygen, high carbon dioxide concentrations, and very low humidity in aircraft cabins may increase respiratory system stress and irritation for persons in aircraft cabins aloft relative to those at or near sea level, especially for non-sedentary flight attendants. ${ }^{312} 185258$

\section{SECONDHAND SMOKE POLLUTION IN AIRCRAFT CABINS}

The second major factor in determining air quality on passenger aircraft is the strength of pollutant sources. A typical cigarette emits an average of $14 \mathrm{mg}$ of RSP when smoked. ${ }^{54}$ The US national average smoking rate was two cigarettes per hour in $1980^{\circ}$ and only $10 \%$ less by 1990 . Despite the fact that smoking emits copious amounts of toxic air pollutants into a small cabin volume, for most of the history of commercial air travel, smoking has been taken for granted. The volume of the aircraft and the maximum person density are fixed by the aircraft design. Thus, the cabin smoker density is essentially dependent upon the number of passengers and the smoking prevalence and smoking rate among those passengers. The overall US population smoking prevalence was $37 \%$ in $1970,33 \%$ in 1980 , and by 1987 , had declined only slightly to $29 \%{ }^{4}$ However, in 1986, the proportion of airline passengers who smoked and requested seating in the smoking section was estimated at $32.3 \%,{ }^{1}$ a reduction by only 13\% from the 1970 smoking prevalence.

In 1986, the National Academy of Sciences ${ }^{1}$ warned that: "ETS [SHS is also called environmental tobacco smoke or ETS] is a hazardous substance and is the most frequent source of complaint about aircraft air quality." ..."Because of the high concentration of ETS generated in the smoking zone, it cannot be compensated for by increased ventilation in that zone. Moreover, ...smoking and non-smoking zones do not prevent exposure of flight attendants ... to ETS, because of the location of galleys and lavatories in the smoking areas. Smoke exposure can become significant in aircraft with outside-air flow rates as low as $7 \mathrm{ft}^{3} / \mathrm{min} /$ passenger. Even a ventilation rate of $14-15 \mathrm{ft}^{3} / \mathrm{min} /$ passenger consists of as much as $50 \%$ recirculated, and possibly smoky, cabin air."..."the Committee feels that this potential threat to the health of...flight attendants should not be ignored." ..."It is highly probable that eye, nose, and throat irritation will increase ... as outside air ventilation rates are decreased and recirculation is increased to improve fuel efficiency." "The Committee recommends a ban on smoking on all domestic commercial flights...to lessen irritation and discomfort to...crew, to reduce potential health hazards to cabin crew associated with ETS, to eliminate...fires, and to bring the cabin air quality into line with established standards for other closed environments." 


\section{MEASUREMENTS OF SECONDHAND SMOKE}

A literature search disclosed a number of measurements of airliner cabin air quality conducted between 1971 and 1998 variously by the government, by the airline industry, and by the tobacco industry. Measurements variously included air pressure, bioaerosols, carbon monoxide (CO), carbon dioxide $\left(\mathrm{CO}_{2}\right)$, formaldehyde, ionizing radiation, nicotine, ozone, relative humidity, total or respirable particulate matter (TSP or RSP), ventilation rates, and volatile organic compounds (VOC). ${ }^{14}$ The best indicators for SHS are gas phase nicotine and RSP. Nicotine is strongly correlated to both gas and particulate phase SHS compound $\mathrm{s}^{20}$; both gas-phase and particulate phase SHS contain many potent carcinogens and toxins. Data from studies of RSP and nicotine on aircraft since 1971 are summarised in tables 1,2 , and 3 . These are identified as those sponsored by the airlines, by government, by non-governmental organisations, and by the tobacco industry, and their conclusions discussed below.

\section{GOVERNMENT SPONSORED STUDIES}

The National Academy of Sciences (NAS) Committee on Airliner Cabin Air Quality study ${ }^{1}$ was commissioned by Congress under Public Law 98-466 as a result of hearings in 1983-84 that revealed that available data on airliner cabin air quality were contradictory. The regulatory community and the airline industry then asserted that industry standards and practices were adequate and that the aircraft environment did not endanger either the health or safety of passengers or crew. The NAS Committee on Airliner Cabin Air Quality reviewed data on air quality, cabin pressure, humidification, cosmic radiation, microorganisms, and pollutants including carbon monoxide, carbon dioxide, ozone, and ETS. The committee noted that aircraft air quality had not been a subject of systematic investigation, but that various airlines had conducted tests, and the committee conducted some spot measurements, generalised by mathematical modelling. The 303 page NRC report recommended that smoking on all domestic flights be banned for four major reasons: to lessen irritation and discomfort for passengers and crew; to reduce potential health hazards to cabin crew from SHS; to eliminate potential fire hazards; and to bring the cabin air quality into line with established standards for other closed environments. The committee pointedly concluded that the lowest rate of cabin ventilation under conditions of nearly full occupancy would be the minimum to provide acceptable air quality when neither SHS nor other (physical) contaminant sources were present.

In a 1989 study funded by the National Cancer Institute, Mattson et $a^{21}$ measured personal nicotine concentrations and urinary cotinine in four flight attendants and five passengers on four, 4 hour Air Canada transcontinental flights, two B-727's, and two B767's. Mattson et al found that attendants assigned to work in non-smoking areas were not protected from smoke. Self reported eye and nasal symptoms and perception of a smoky atmosphere were significantly related to nicotine and cotinine, and both were correlated to annoyance as well, although the positive cotinine trend was not significant. Mattson et $a^{21}$ concluded that SHS exposures on aircraft create a health risk, acute irritation, and annoyance to non-smokers.

In 1989, the US Department of Transportation sponsored the first comprehensive study of airliner cabin air quality. ${ }^{32}$ Its purpose was "to develop information to be used for determining health risks from exposure to SHS and other pollutants for airliner occupants". Selected SHS contaminants (nicotine, RSP, $\mathrm{CO}$ ) as well as $\mathrm{CO}_{2}$, ozone $\left(\mathrm{O}_{3}\right)$, microbial aerosols, cabin pressure, relative humidity, and temperature were measured in 92 randomly selected aircraft. Both RSP and nicotine correlated strongly with observed smoking rates, and under actual operating conditions, variability in the overall average SHS-RSP to SHS-nicotine ratio was small, yielding a range of 11.0-12.5.

For all smoking flights, domestic and international, the average number of passengers in the smoking section was 18 , and ranged from 2-63; the average percentage of passengers in the smoking section was $13.7 \%$, and ranged from $1.4-$ $41.9 \%$, and the average number of cigarettes smoked per passenger hour was 1.5 (range 0.2-6.5). ${ }^{3}$ There was evidence for migration of SHS-RSP into the non-smoking sections. Ozone levels were well within standards, while relative humidity averaged $<16 \%$, and cabin pressure averaged $661 \mathrm{~mm} \mathrm{Hg}(760 \mathrm{~mm} \mathrm{Hg}$ is sea level). Ventilation rates did not limit $\mathrm{CO}_{2}$ levels to the ASHRAE (American Society of Heating, Refrigerating, and Air Conditioning Engineers) standard for comfort of $1000 \mathrm{ppm}$. Nagda et al generalised their measurements by mathematical modelling, and conducted a carcinogen risk assessment using two dose-response models. Nagda et al recommended a total or partial ban on smoking as "measured values...were well within the range associated with irritancy response and unacceptable cancer risk for the general population" ${ }^{\prime 1}{ }^{19}$

For eight randomly selected international flights, RSP results reported by Nagda $e t a^{322}$ are given in fig l. Figure 1 plots RSP concentration on smoking and non-smoking flights as a function of seating position with respect to the smoking section in the aircraft. These involved wide body aircraft, including five B747s, one B-767, and two MD DC10s. ${ }^{3}$ The average load factor (per cent of seating capacity filled by passengers) was $64 \%{ }^{3}$ Figure 1 shows that smoking elevates peak RSP levels by 100-fold, and average RSP levels by 15 fold in the smoking section, and that the non-smoking section (boundary, middle, and seats most remote from smoking) on smoking flights is considerably contaminated with fine particle pollution relative to non-smoking flights. Multiple studies on aircraft have reported ${ }^{3}$ peak levels of fine particles, characteristic of SHS-RSP, in the range of 750$1200 \mu \mathrm{g} / \mathrm{m}^{3}$. Such peaks assume even greater importance when flight attendants' activity patterns are taken into account: peaks appear to occur after meals while flight attendants may be servicing the cabin, ${ }^{3}$ increasing proximity to smoking and elevating attendants' SHS doses beyond what area monitors of SHS concentrations would suggest. Such peaks assume greater import when acute irritating effects of tobacco smoke are considered.

A US National Institute for Occupational Safety \& Health (NIOSH) study, performed by Waters et al ${ }^{23}$ between 1995 and 1998, investigated cabin environmental contaminants on 36 US commercial aircraft, including a number of international flights. RSP levels were measured on smoking flights, but not on non-smoking flights. Peak levels of RSP in rear coach were substantially higher than front coach due to smoking ( $M$ Waters, personal communication). Gate-to-gate times varied from 42 to 863 minutes, and passenger occupancy in coach from $34 \%$ to $100 \%$ of capacity. $\mathrm{CO}_{2}$ exposures (the higher the poorer the ventilation) were highest on shorter and high occupancy flights, aircraft with a higher degree of recirculation, and narrow bodied aircraft..$^{23}$ NIOSH concluded that $\mathrm{CO}_{2}$ levels indicated lower ventilation rates per occupant than most other indoor environments, a likely result of the fact that commercial aircraft are not required by the Federal Aviation Administration to meet performance criteria with respect to either outside or recirculation air. ${ }^{23}$

\section{AIRLINE STUDIES}

In 1997, an SAS funded study by Lindgren et al ${ }^{24}$ assessed perception of air quality by questionnaire in 1857 Stockholm based SAS aircrew and measured cabin air quality (RSP, 


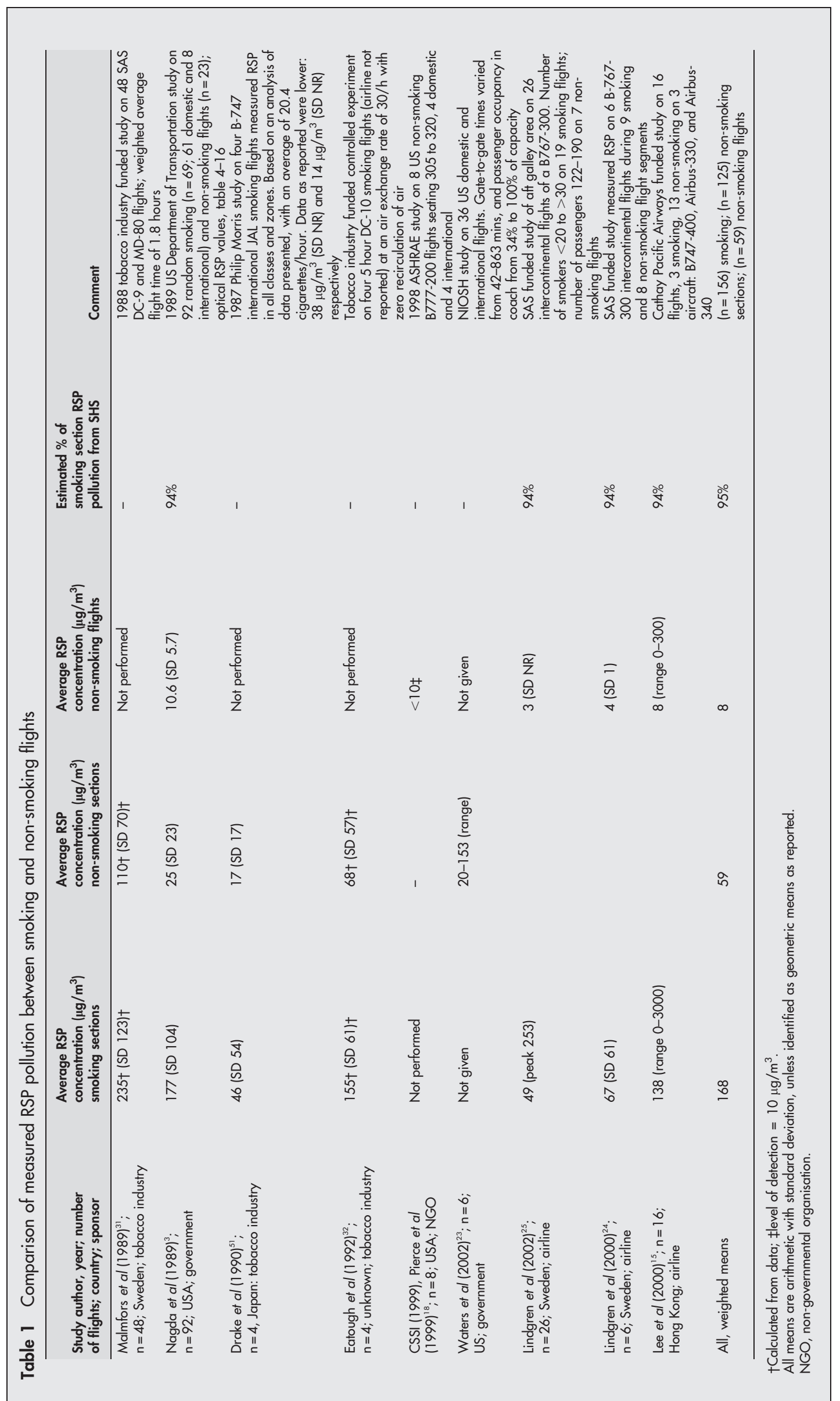




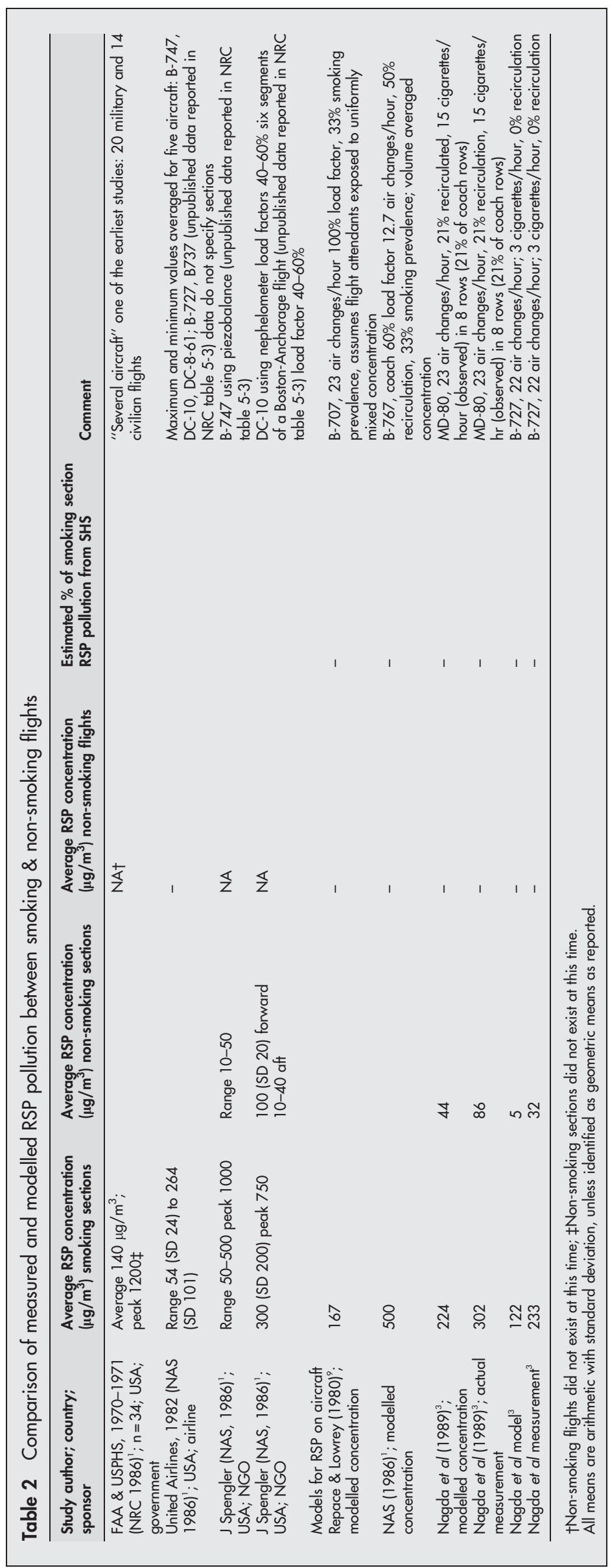




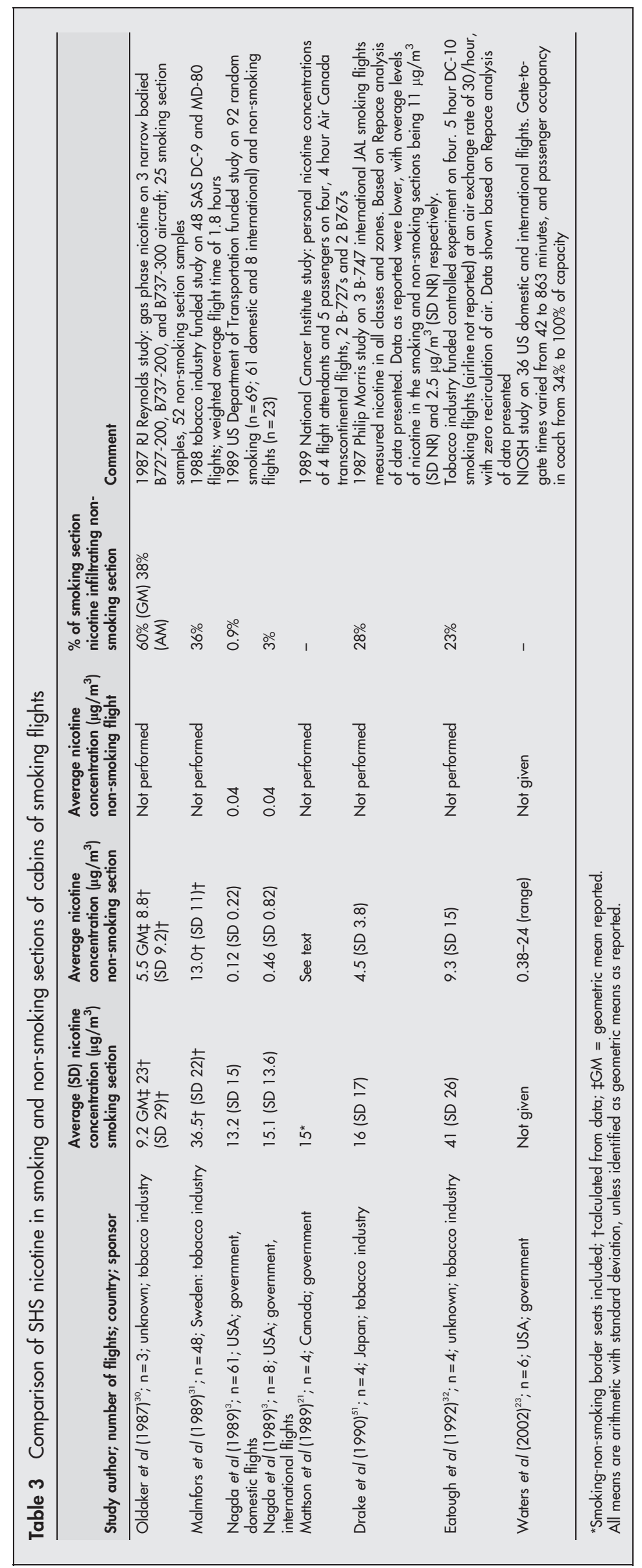




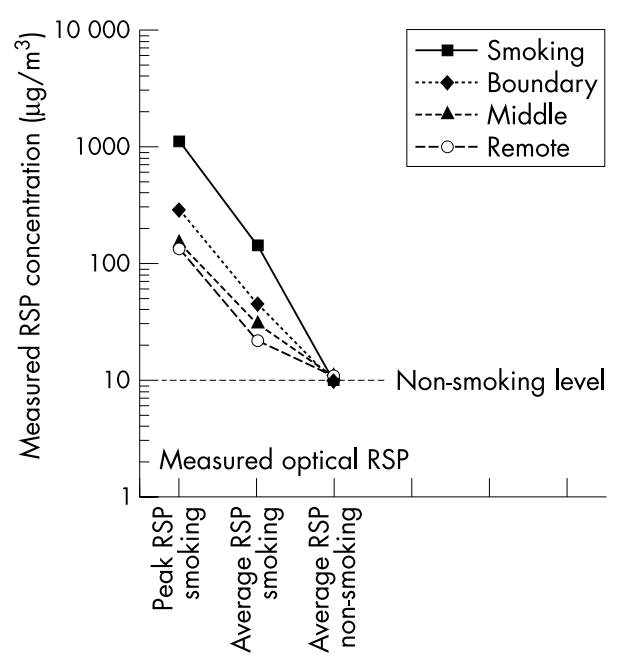

Figure 1 Measured RSP concentrations on eight international flights by seat location (Nagda et a $\beta^{\beta}$ table 5-2; table 4-22). "Smoking" refers to seats in the smoking section, while "Boundary", "Middle", and

"Remote" refer to seats in the non-smoking section, and describe their proximity to the smoking section. The dotted line indicates the RSP level on non-smoking flights.

relative humidity, $\mathrm{CO}_{2}$, and temperature) on six B-767-300 intercontinental flights during nine smoking and eight nonsmoking flights (190 seats, 50\% recirculated air; cabin pressure 2000-2500 m; cabin volume $428 \mathrm{~m}^{3}$ ). ${ }^{24}$ A control group of 218 office workers was used for comparison. Cabin humidity was very low (5\%), and $\mathrm{CO}_{2}$ levels were below $1000 \mathrm{ppm}$. Annoyance from SHS was common among all aircrew work categories in the cabin $(20-43 \%)$ but uncommon on the flight deck $(4 \%)$ and in the office $(8 \%)$. Effects were more common among atopic and younger crew. Lindgren et al $^{24}$ concluded that tobacco smoking onboard leads to significant respirable particle pollution. Lindgren and Norbäck $^{25}$ studied RSP in the aft galley area on 26

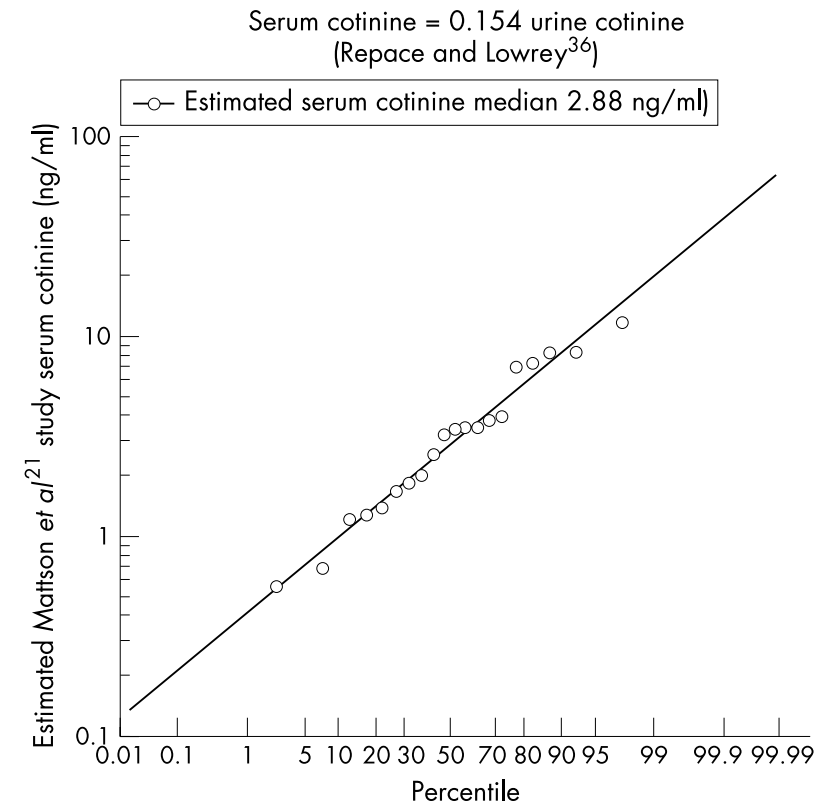

Figure 2 Log probability plot of the serum cotinine 12 hour postexposure for the nine subjects on the Mattson et al ${ }^{21}$ study, estimated from the creatinine normalised urinary cotinine $(\mathrm{ng} / \mathrm{ml}$ ) for subjects reporting no inter-flight SHS exposure (adapted from an analysis of fig 2 in Mattson et al' ${ }^{21}$. intercontinental flights of a B767-300 with and without tobacco smoking. They concluded that, despite the high air exchange rate and efficient air filtration on these flights, smoking in commercial aircraft leads to significant pollution and should be prohibited. ${ }^{25}$

A Cathay Pacific Airways study conducted in 1996-97 by Lee et $a l^{15}$ measured RSP by nephelometry on 16 flights of three wide bodied aircraft operating out of Hong Kong: the Boeing 747-400, Airbus-330, and Airbus-340. For three smoking flights, load factors were $60 \%, 60 \%$, and $91 \%$. The authors observed that there were major differences in the SHS concentration measured on smoking and non-smoking flights in the same cabin location.

\section{NGO STUDY}

In a study sponsored by ASHRAE, air quality was assessed on eight US carrier non-smoking flights on a B777-200 seating 305 to 320 passengers in July 1998, four each, domestic and international. ${ }^{1827}$ The outside air ventilation rate was $10 \mathrm{ft}^{3} /$ min per person; HEPA-filtered air was recirculated at a rate of $10 \mathrm{ft}^{3} /$ min per person. The mean $\mathrm{CO}_{2}$ level in the aft galley and economy class respectively with recirculation on was 2840 parts per million (ppm), and $1405 \mathrm{ppm}$, and with recirculation off, $1350 \mathrm{ppm}$ and $798 \mathrm{ppm}$. The report concluded that $\mathrm{CO}_{2}$ levels averaged about 50\% higher than recommended ${ }^{28}{ }^{29}$ by ASHRAE for public buildings. Insofar as perceptions of air quality, $3.2 \%$ of the passengers but $17.7 \%$ of the flight attendants rated air quality as "poor or very poor". Flight attendants' three top complaints were skin dryness or irritation, dry or stuffy nose, and dry itchy or irritated eyes. The report ${ }^{18}$ concluded that RSP levels on these non-smoking flights were "very low" compared to other indoor environments. RSP levels $(0.1-10 \mu \mathrm{m})$ were measured by continuous reading optical nephelometry with the level of detection being $10 \mu \mathrm{g} / \mathrm{m}^{3}$. All readings were below the level of detection.

\section{TOBACCO INDUSTRY STUDIES}

The tobacco industry has taken a major interest in the issue of smoking on aircraft. In 1987, Oldaker \& Conrad, ${ }^{30}$ in an RJ Reynolds Tobacco Company study, measured gas phase nicotine on three narrow bodied B727-200, B737-200, and B737-300 aircraft. They concluded that average exposures in the non-smoking section were "insignificant compared to smoking a single cigarette", and that the aircraft ventilation systems were primarily responsible. A second tobacco industry funded study in 1988 by Malmfors et $a l^{31}$ measured RSP and nicotine on 48 SAS DC- 9 and MD- 80 flights. The authors concluded that exposure to SHS on aircraft "is insignificant compared to total life exposure to indoor air pollutants" and that "an effective ventilation system is essential for cabin air quality". A third Philip Morris tobacco company funded study by Drake and Johnson, ${ }^{51}$ undertaken in 1987 on four B-747 international JAL smoking flights, measured RSP and nicotine in all classes and zones. Drake and Johnson ${ }^{51}$ concluded that "the 747's five air conditioning zones are reasonably effective in keeping SHS within the respective zones, and discharging it with relatively little entry into non-smoking areas".

A fourth study funded by the tobacco industry in 1992 investigated the variability of SHS tracers in a controlled experiment conducted on four, 5 hour DC-10 smoking flights (airline not reported) at a rate of 30 air changes per hour, with zero recirculation of air. Eatough et $a l^{32}$ reported that SHS pollutants penetrating into the non-smoking section decay exponentially, with nicotine decaying faster than other species, and that additional data were needed to determine what variables control the rate of penetration. Eatough et al concluded that while the concentration of most SHS 
constituents can be calculated from the frequency of smoking, the size of the smoking section, and the ventilation rate, neither RSP nor nicotine could be accurately predicted by modelling. In 1991, a fifth publication by Crawford and Holcomb, ${ }^{33}$ who did not advise that they were tobacco industry consultants, concluded in a review that "the very low levels of ETS in airliners do not appear to pose a measurable risk to health of passengers or flight attendants". Crawford asserted earlier ${ }^{34}$ that high ventilation rates on aircraft "effectively control all pollutions"; Holcomb earlier claimed $^{35}$ that SHS is unfairly blamed for discomfort "due to its visibility".

\section{NCI FLIGHT ATTENDANT DOSIMETRY STUDIES}

The foregoing air quality monitoring studies are not measures of the actual SHS dose received by flight attendants, because area monitors do not reflect absorbed dose. Flight attendants' SHS dose was measured by cotinine dosimetry in an important study sponsored by the National Cancer Institute (NCI). Mattson et $a l^{21}$ measured cabin air nicotine exposure and urinary cotinine dose in four flight attendants and five passengers on two international (San Francisco to Toronto and back) and two transcontinental (Toronto to Vancouver) smoking flights on Air Canada in May 1988. All subjects were non-smokers with no regular exposure to smoke, and were free of respiratory disorders. The first two flights were on B-727 narrow body jets with $100 \%$ fresh air. The latter two flights were on B-767 wide bodies, with $50 \%$ of the air recirculated. The same subjects were monitored in all flights (five passengers who sat in the smoking section or on its border, and four flight attendants who rotated assignments to smoking for half the flights and to non-smoking for the other half). Seventy two to 96 hours elapsed between flights. Air nicotine exposure via personal monitoring pumps and filters was assessed during the flight. Cigarettes were counted at intervals during the flights, and the extent and duration of between flight exposure to SHS was monitored by passive monitors and recorded in diaries.

Urinary cotinine excretion (normalised for creatinine) was sampled pre-flight and post-flight cotinine was collected over the 72 hour period following the flight. Subjects collected all their urine for each of 12, 6 hour periods post-flight. All subjects were non-smokers with no regular exposure to tobacco smoke, had their between flight exposure monitored with both a diary and passive nicotine monitor, and had preboarding baseline urine samples in addition to the 72 hour post-exposure urine collection. Significant differences in cotinine levels were observed over a 72 hour period between in-flight high nicotine exposures and low ones (that is, less than the median value). Mattson et $a l^{21}$ correlated natural logarithms of nicotine and 12 hour post-exposure cotinine for subjects not re-exposed between flights $\left(R^{2}=0.74\right.$, $\mathrm{p}=0.0003$ ).

Analysis of the nicotine data presented shows that personal nicotine monitors for the four attendants registered levels averaging $4.7 \mu \mathrm{g} / \mathrm{m}^{3}$ (SD 4.0) while the five passengers averaged $15 \mu \mathrm{g} / \mathrm{m}^{3}$ (SD 20) with an average of about $n_{\mathrm{s}}=4$ active smokers (SD 0.2 ) in four smoking rows during the smoking portion of the flights. Four active smokers is equivalent ${ }^{9}$ to 12 habitual smokers, or about $9-12 \%$ of total passengers. Mattson et al reported that attendants worked in both smoking and non-smoking areas when they were assigned to the smoking area. Some non-smoking areas on board the aircraft had levels comparable to those in smoking sections. Exposure of attendants assigned to work in smoking was not significantly different from that of attendants who worked in non-smoking. Exposure among attendants was reported not statistically different from that of passengers, although none of the eight high nicotine exposures observed on the flights occurred among attendants. ${ }^{21}$

\section{URINE AND SERUM COTININE FOR THE AIR CANADA FLIGHT ATTENDANTS}

Repace et $a l^{36}{ }^{37}$ developed pharmacokinetic models from which cotinine in blood, urine, and saliva can be compared. These models accurately predicted levels found in observational studies of cotinine dose levels in non-smoking office workers and other cohorts. For example, Repace et $a l^{37}$ estimated the median salivary cotinine dose of a typical office worker in an office with a $29 \%$ smoking prevalence and ventilated according to ASHRAE Standard 62-1989, as $\mathrm{S}=0.5 \mathrm{ng} / \mathrm{ml}$; this was the same as the observed median of $0.5 \mathrm{ng} / \mathrm{ml}$ measured in 89 office workers; the corresponding estimated serum cotinine equivalent is $\mathrm{P}=\mathrm{S} / 1.16=$ $0.43 \mathrm{ng} / \mathrm{ml}$, close to that measured in the NHANES III survey discussed below.

The anti-logarithms of Mattson et al' $\mathrm{s}^{21}$ urine cotinine data are calculated and presented de novo in table 4, column 1; data for attendants and passengers with interflight exposure is excluded. The Air Canada flight attendant urine cotinine dose from table 4 may be converted into its serum cotinine equivalent using the urinary cotinine ( $U$, $\mathrm{ng} / \mathrm{ml})$ to serum cotinine $(\mathrm{P}, \mathrm{ng} / \mathrm{ml})$ conversion equation ${ }^{36}{ }^{37}$ : $\mathrm{P}=\mathrm{U} / 6.5=0.154 \mathrm{U}$ (equation 1 ).

Using equation 1 , the range of estimated serum cotinine for the Air Canada study flight attendants is about a factor of 20 , from $\mathrm{P}=0.55$ to $11.54 \mathrm{ng} / \mathrm{ml}$, with a median value of $\mathrm{P}_{\text {med }}=(0.154)(18.72)=2.88 \mathrm{ng} / \mathrm{ml}($ fig 2$)$.

These urinary cotinine doses may be put into perspective by comparing their measures of central tendency to those of a national probability sample of cotinine collected by the Centers for Disease Control (CDC). Figure 3 compares the median for the subjects in the Mattson study ${ }^{21}$ to the serum cotinine distribution for the NHANES III probability sample of all US adults exposed either at work or at home during 1988-1991. ${ }^{38}$ The average US adult had a geometric mean dose of $0.205 \mathrm{ng} / \mathrm{ml}^{38}$ (For an ideal log normal distribution, the median and geometric mean are the same..$^{40}$ ) This is more than seven times the US population (1988 to 1991) median serum cotinine value for non-smoking workers reporting exposure to SHS only at work from the NHANES III study (D Mannino, personal communication, US Centers for Disease Control, 1999) of $\mathrm{P}_{\text {US med. }}=0.393 \mathrm{ng} / \mathrm{ml}$. This is close to the geometric mean for the same worker group as reported ${ }^{38}$ for the probability sample for the US population of workers exposed to SHS at work alone: $\mathrm{P}_{\text {US }}$ g.m. $=0.468 \mathrm{ng} / \mathrm{ml}$. This is summarised in table 5 . Moreover, table 4 and fig 3 show that $100 \%$ of the serum cotinine doses estimated from the measurements in the Mattson study during May 1988 exceeded those of the average US worker in CDC's NHANES III contemporaneous study measured during 1988-1991, indicating that the Air Canada flight attendants have been exposed to SHS at much greater levels than the average US worker.

\section{GENERALISATION OF THE AIR CANADA STUDY}

How do the Air Canada B-727s and 767s compare to others in service? Table 6 gives the nominal cabin volumes, extent of air recirculation, and air exchange rates for one narrow body and five wide body types. ${ }^{3}$ All aircraft have a very low volume per person. How does this airspace compare with that afforded office workers? By comparison, a typical office has an occupancy of seven persons per thousand square feet, and for a 10 foot ceiling, an occupancy of seven persons per $10000 \mathrm{ft}^{3}$ or per $283 \mathrm{~m}^{3}$, yielding a space volume of $40.4 \mathrm{~m}^{3}$ per person. ${ }^{39}$ Thus, a typical office worker has (40.4/1.5) 27 times more airspace per occupant than a typical flight 
Table 4 Urinary cotinine for four flight attendants and five passengers not re-exposed to SHS between flights: on four Air Canada flights, two B727s and two B767s, analysed from data presented in fig 2, in Mattson et al, ${ }_{1}^{21}$ with serum cotinine estimated from Repace and Lowrey's ${ }^{36}$ pharmacokinetic model: $P=0.154 \mathrm{U}$

\begin{tabular}{|c|c|c|}
\hline & $\begin{array}{l}\text { Measured } 12 \text { hour post-flight creatinine } \\
\text { normalised cotinine (ng/ml-mgCr) }\end{array}$ & $\begin{array}{l}\text { Estimated } 12 \text { hour post-flight serum } \\
\text { cotinine }(\mathrm{ng} / \mathrm{ml})\end{array}$ \\
\hline & 74.94 & 11.540 \\
\hline & 53.60 & 8.2500 \\
\hline & 53.60 & 8.2500 \\
\hline & 47.42 & 7.3000 \\
\hline & 45.06 & 6.9400 \\
\hline & 25.58 & 3.9400 \\
\hline & 24.43 & 3.7600 \\
\hline & 22.81 & 3.5100 \\
\hline & 22.57 & 3.4800 \\
\hline & 22.10 & 3.4000 \\
\hline & 20.98 & 3.2300 \\
\hline & 16.46 & 2.5400 \\
\hline & 13.01 & 2.0000 \\
\hline & 11.94 & 1.8400 \\
\hline & 10.70 & 1.6500 \\
\hline & 8.87 & 1.3700 \\
\hline & 8.21 & 1.2600 \\
\hline & 7.85 & 1.2100 \\
\hline & 4.47 & 0.69000 \\
\hline & 3.57 & 0.55000 \\
\hline Mean (SD & 24.91 (19.71) & $3.84(3.04)$ \\
\hline Median & 18.72 & 2.88 \\
\hline
\end{tabular}

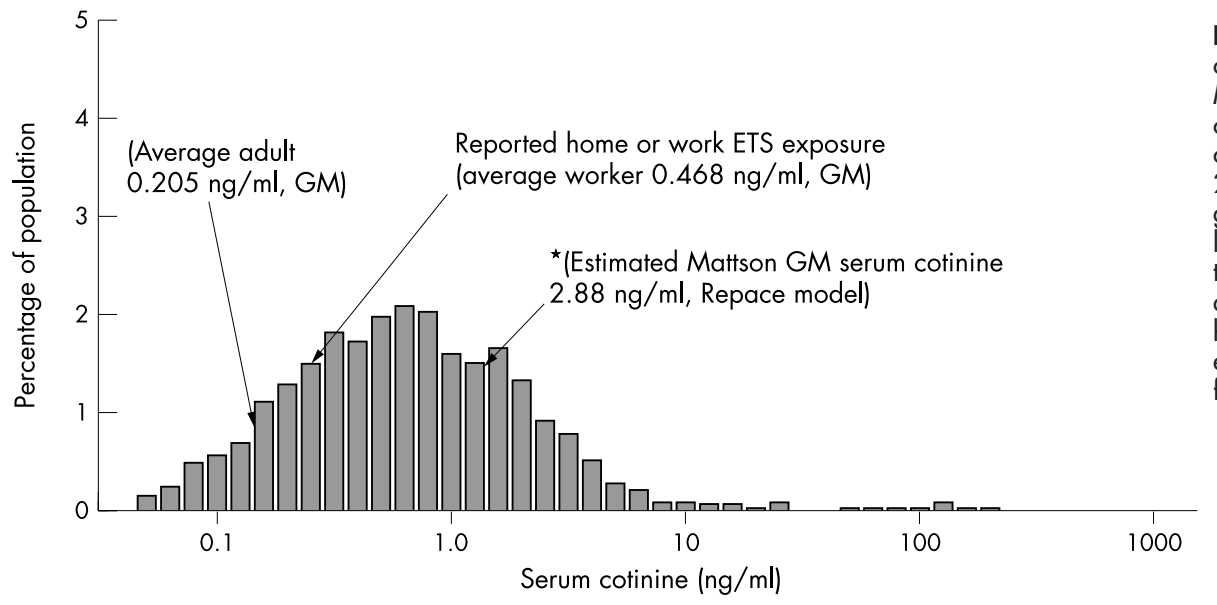

Figure 3 NHANES III distribution of cotinine in the US population versus the Mattson study. The median serum cotinine equivalent to the urinary cotinine level of $18.72 \mathrm{ng} / \mathrm{ml}$ is $2.88 \mathrm{ng} / \mathrm{ml}$, which is six times the geometric mean (GM) serum cotinine level of the average US worker and 14 times that of the average adult, demonstrating that flight attendants have had abnormally heavy SHS exposure. NHANES III cotinine data from Pirkle et al. ${ }^{38}{ }^{*}$ Repace et al. ${ }^{36}{ }^{37}$

attendant. An aircraft cabin at $100 \%$ load factor has a $4-$ 10 litres/s per person ventilation rate, compared to an office rate 10 litres/s per person. The aircraft person density ${ }^{7}$ in the smoking section, 168 persons per $1000 \mathrm{ft}^{2}$, is greater than the 150 persons per $1000 \mathrm{ft}^{2}$ in a stand up bar with a ventilation rate of $15-25$ litres/s per person, ${ }^{28}$ or the 100 persons per $1000 \mathrm{ft}^{2}$ for an ordinary bar, at 15 litres/s per person, ${ }^{39}$ and is much greater than the 70 persons per $1000 \mathrm{ft}^{2}$ for a smoking lounge ventilated at 30 litres/s per person..$^{29}$ Assuming a $10 \mathrm{ft}$ ceiling, the smoking lounge has $4 \mathrm{~m}^{3}$ per smoker, twice that of the aircraft, and has more than triple the ventilation rate, while the stand-up bar has $1.9 \mathrm{~m}^{3}$ per person; if half of those persons are smokers, this is also about $4 \mathrm{~m}^{3}$ per smoker, with 2-5 times the aircraft ventilation rate.

Although limited in number of subjects exposed in flight, the cotinine studies suggest that SHS exposure of flight

Table 5 Comparison of aircraft SHS dose with ground based dose for workers

\begin{tabular}{|c|c|c|c|}
\hline $\begin{array}{l}\text { Cotinine study; number of } \\
\text { workers }\end{array}$ & $\begin{array}{l}\text { Median serum cotinine } \\
\text { level }(\mathrm{ng} / \mathrm{ml} \text { ) }\end{array}$ & Exposure venue & $\begin{array}{l}\text { Estimated ratio to } \\
\text { average worker }\end{array}$ \\
\hline $\begin{array}{l}\text { Mattson et } a l^{21} ; \mathrm{n}=9 \\
\text { NHANES III, Mannino } \\
\text { (personal communication) } \\
\text { NHANES III, Pirkle et } a l^{38} ; \\
\mathrm{n}=12000\end{array}$ & $\begin{array}{l}2.88^{*} \\
0.393 \\
0.468 \dagger\end{array}$ & $\begin{array}{l}\text { Exposed on aircraft } \\
\text { US workers, national } \\
\text { sample } \\
\text { US workers, national } \\
\text { sample }\end{array}$ & $\begin{array}{l}6.1-7.3 \\
1.0 \\
1.0\end{array}$ \\
\hline
\end{tabular}


Table 6 Cabin volumes, percentage air recirculation, and air exchange rates ${ }^{1} 311$

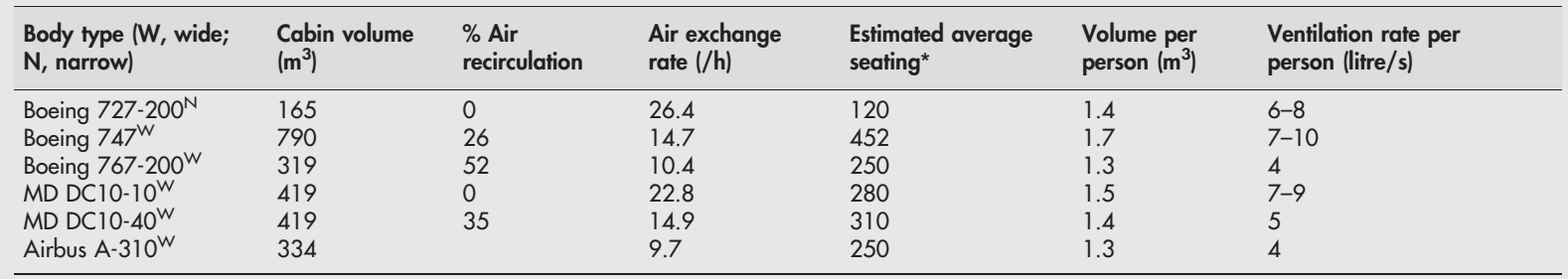

The B-747 has a passenger capacity of $331-550$ persons, and the DC-10 from 250-380 persons.

${ }^{*}$ At $100 \%$ load factor.

attendants in general has been much greater than for average workers in ground based microenvironments. As discussed, the aircraft cabin has much less ventilation per person and much less space per person than offices, bars or smoking lounges. The latter is important because proximity to a pollution source increases exposure ${ }^{42}{ }^{3}$-flight attendants have been exposed to tobacco smoke of passengers at distances approaching $0.5 \mathrm{~m}$. The RSP and nicotine concentrations reported in tables $1-3$ are measured by area monitors remote from the flight attendants' breathing zone, where they encounter more concentrated cigarette plumes as they serve smoking passengers. Area monitors cannot reflect flight attendants' respiration rates as they work or their mobility in the cabin. In other words, the SHS concentration in the breathing zone of a flight attendant may be significantly underestimated by the stationary area monitors which have been used in nearly all studies of SHS on aircraft. The best evidence of flight attendants' true exposure to SHS is therefore derived from cotinine dosimetry. Dosimetry, which incorporates proximity, duration, and respiration rate, is the gold standard in exposure assessment. ${ }^{37}$

\section{DISCUSSION}

Based upon stationary air monitoring studies in $\sim 250$ flights, levels of SHS-RSP are considerably higher on smoking flights than non-smoking flights, as summarised in tables 1 and 2 . Based on these data, it appears that $\sim 94 \%$ of the RSP pollution in the smoking section on aircraft is due to smoking. On a weighted mean basis, about $95 \%$ of the smoking section pollution, $160 \mu \mathrm{g} / \mathrm{m}^{3}$, is from SHS. Similarly, when the weighted arithmetic mean of four studies of RSP in non-smoking sections on smoking flights $(\mathrm{n}=125), 59 \mu \mathrm{g} /$ $\mathrm{m}^{3}$, is compared to that of the five studies of RSP on nonsmoking flights $(\mathrm{n}=59), 8 \mu \mathrm{g} / \mathrm{m}^{3}$ (SD 3.3), most, (5l/59) $(100 \%)$ or $86 \%$ of the RSP in aircraft cabin non-smoking sections on smoking flights is estimated to come from SHS. This is supported by the nicotine studies in table 3 which show significant nicotine contamination in both smoking and non-smoking sections of aircraft on smoking flights, and the virtual absence of nicotine on non-smoking flights, and generalised by the models for SHS-RSP reported in table 3. It is evident that established aircraft ventilation rates and smoking rates must result in SHS-RSP levels of the order of several hundred micrograms per cubic meter.

Many epidemiological studies have shown that increases in daily average RSP levels are associated with increased morbidity and mortality. ${ }^{44}$ The current US federal standard for $\mathrm{PM}_{2.5}$ is $15 \mu \mathrm{g} / \mathrm{m}^{3}$, annual average. In 1980, the annual federal standard for TSP was five times higher, at $75 \mu \mathrm{g} / \mathrm{m}^{3}$. Repace and Lowrey ${ }^{9}$ observed that a flight attendant working 40 hours per week would violate the (now obsolete) TSP standard by a factor of 1.2. Scaling this to the new $\mathrm{PM}_{2.5}$ standard and a more realistic 20 hour flight attendant workweek, ${ }^{8}$ yields a $(1.2)(75 / 15)(20 / 40)=3$-fold violation of the $\mathrm{PM}_{2.5}$ standard. This standard is designed to protect against such fine particle health effects as: premature death, increased emergency room visits and hospital admissions, increased respiratory symptoms and disease, decreased lung function, and alterations in lung tissue and structure and in respiratory tract defence mechanisms. ${ }^{45}$

In addition, SHS is a well established sensory irritant, variously producing itching, tearing, burning, swelling of eyes, sneezing, blocking, running, itching of nose, headache, cough, wheezing, sore throat, nausea and dizziness, and respiratory discomfort. ${ }^{45105354}$ A recent Swiss study by Junker et $a l^{46}$ reported an odour acceptability threshold of $1 \mu \mathrm{g} / \mathrm{m}^{3}$ SHS-RSP, and a SHS-RSP irritation threshold level of $4.4 \mu \mathrm{g} / \mathrm{m}^{3}$ SHS-RSP, compared to an RJ Reynolds tobacco company study, ${ }^{47}$ which reported a SHS-RSP sensory (eye, nose, and throat) irritation threshold level of $58 \mu \mathrm{g} / \mathrm{m}^{3}$. At that $4.4 \mu \mathrm{g} / \mathrm{m}^{3}$ SHS-RSP level, only $33 \%$ of non-smoking test subjects found the air quality acceptable. The smoking section SHS-RSP level of $160 \mu \mathrm{g} / \mathrm{m}^{3}$ of table 1 is nearly triple the RJ Reynolds study's irritation threshold. This SHS-RSP pollution level is also 36 times the Swiss study's eye, nose, and throat irritation threshold, and peak SHS-RSP pollution levels are sixfold higher than the mean, as illustrated in fig 1 . The Swiss study ${ }^{46}$ threshold will be used in this work.

Work related studies of SAS flight attendants during the late 1980s showed that two thirds of flight attendants surveyed reported suffering discomfort "to a great extent" from tobacco smoke. ${ }^{7}$ In the words of one US flight attendant: "It was impossible to avoid tobacco smoke exposure no matter where I worked on the planes: although the areas that were designated smoking were...more concentrated, ...the whole cabin reeked of smoke. You could smell and see it throughout the entire cabin". "You just couldn't avoid it. It was always worse on an airplane than in restaurants or bars, because there you could move or leave." ${ }^{\prime 41}$ In the words of another: "Nonsmoking flight attendants were frequently asked by their doctors how long they'd been smoking...dentists would remove tobacco stains from their teeth,...burning eyes and bloody nostrils were considered normal...you lived with a dull headache, nasal burning and lowered energy...". ${ }^{55}$ Anecdotes of this nature and more poignant ones were expressed by the flight attendant panel at the 1989 Congressional hearing. In the opinion of this observer, who testified at that hearing as a member of the federal panel, it was precisely such tales of suffering that gave life to the scientific data, and moved the Aviation Subcommittee to pass the six hour airline smoking ban. The second attendant further related: "In the years since SHS has been banned on aircraft, many of us have had a profound improvement in our symptoms..."155

In summary, the studies of airliner cabin air quality showed that tobacco smoke was a significant source of air pollution in aircraft cabins, that this tobacco smoke was absorbed by flight attendants and passengers, and that ventilation, the only available tool to limit SHS exposure on aircraft other than a smoking ban, was declining precipitously because of economic forces. All studies of SHS on aircraft yielded similar results; those sponsored by government, 
airlines, the tobacco industry, and NGOs. By the mid1980s, SHS had been identified by both the NAS and the Surgeon General as a carcinogen and respiratory toxin as well as a major irritant. ${ }^{15}$ The limitations on ventilation were emphasised by the chair of the ASHRAE 62 Ventilation Standard Committee in 1989: "Dilution of tobacco smoke with outdoor air is an imperfect control mechanism. It depends not only on the amount of dilution air, but on the degree of mixing achieved, convection currents, electrical space charge effects, and perhaps other factors. Therefore elimination of health risk through increased ventilation alone may not be possible" ${ }^{\prime \prime 8}$ [emphasis added]. By contrast, the tobacco industry declaimed from the highest corporate levels that airline smoking bans were unjustifiable, ${ }^{49}$ that SHS levels in airline cabins were "miniscule", and that adequate ventilation addressed poor air quality, ${ }^{50}$ even after the Environmental Protection Agency ${ }^{10}$ and others ${ }^{53}$ had estimated thousands of US deaths annually from SHS.

\section{CONCLUSIONS}

- Flight attendants were exposed to elevated levels of fine particle pollution (RSP) on aircraft for many decades. After smoking was no longer permitted on aircraft, about 95\% of the RSP in the smoking sections of the aircraft cabin and $85 \%$ of the pollution in the non-smoking sections disappeared, relieving a substantial air pollution burden.

- Comparison of the SHS dose levels measured in a small but well done study of flight attendants with those measured in a national probability sample of the US population suggests that flight attendants had about 6 to 7 times the SHS exposure of typical ground based workers, and 14 times that of the typical person.

- Studies of SHS contaminants on aircraft funded by the government, the airlines, non-governmental organisations, and the tobacco industry yielded similar concentrations. However, while the government and airline studies concluded that SHS caused an air pollution problem for passengers and crew, the tobacco industry asserted that SHS was adequately controlled by ventilation systems, and aggressively opposed smoking bans.

- The area, volume, and ventilation rate per smoker on aircraft is the smallest of any social setting, including stand-up bars and smoking lounges.

- While US smoking prevalence declined by $22 \%$ from 1970 to 1987 , aircraft smoking prevalence declined by only $13 \%$. However, cabin ventilation rates declined by $33-60 \%$, during the same period. Thus, aircraft air exchange rates dropped about three times faster than aircraft smoking prevalence.

- Measurements of contaminants in both smoking and nonsmoking sections compared to personal monitoring of flight attendants indicate that separation of the cabin into smoking and non-smoking sections did not significantly reduce flight attendants' exposure to SHS, due to their mobility.

- A study of flight attendants during the late 1980s showed that two thirds complained of suffering "to a great extent" from secondhand smoke exposure. Typical levels of SHSRSP found in smoking sections of aircraft are found to have violated current federal air quality standards by an estimated threefold, and exceeded threshold levels for SHS irritation by one to two orders of magnitude.

- These results have implications for studies of the past and future health of flight attendants.

\section{What this paper adds}

For years, passengers and cabin crew repeatedly complained about poor air quality in aircraft cabins caused by secondhand smoke (SHS). In 1973, in response to passengers' complaints, the US Civil Aeronautics Board established non-smoking sections in passenger aircraft cabins, creating zones of higher and lower SHS pollution. However, it remained until 1989 for the US Congress to ban smoking on flights up to six hours duration, largely to protect cabin crew. Smoking bans subsequently spread internationally. However, many longer duration international flights remained polluted with tobacco smoke until the final years of the 20th century. Despite decades of complaints, air quality and dosimetry data on flight attendants' exposures to SHS have been measured on only a relatively small number of flights. These data were interpreted by government, non-governmental organisations, and airlines to support the need for smoking bans to control SHS pollution in aircraft cabins, and by the tobacco industry to support the contention that ventilation systems controlled SHS, obviating the need for smoking bans.

Using information on aircraft ventilation rates and smoker densities, coupled with air quality data collected before and after the aircraft smoking ban, this paper generalises measurements of atmospheric markers for SHS in aircraft cabins and biomarkers for SHS exposure in flight attendants into a new perspective. It shows that aircraft ventilation systems were incapable of controlling SHS, such that nearly all of the harmful SHS respirable particulate (RSP) air pollution in both the smoking and non-smoking sections of aircraft cabins was from SHS. It appears that 21 st century health based federal air quality standards for RSP were seriously compromised for flight attendants in aircraft cabins during the 20th century smoking era, and that SHS-RSP levels massively exceeded recently measured SHS irritation thresholds. Further, flight attendant dosimetry indicates that workplace SHS exposures in aircraft cabins were far greater than for typical non-smokers in the general population. This has implications for studies of the impact of flight attendants' workplace SHS exposures on their past and future health.

\section{ACKNOWLEDGEMENTS}

The author is grateful to the Flight Attendant Medical Research Institute for support of this work, and thanks NL Nagda, WR Ott, LA Wallace, and MA Waters for helpful discussions.

The author testified before the House Subcommittee on Aviation on the risks from SHS to flight attendants in 1989, served as an advisor to the US Department of Transportation's Airline Cabin Air Quality Study in 1988, and since 1998, has served as an expert witness for the plaintiffs in litigation involving flight attendants, airlines, and the tobacco industry.

\section{Authors' affiliations}

J Repace, Repace Associates, Inc, 101 Felicia Lane, Bowie, 20720, USA; repace@comcast.net. Visiting assistant clinical professor, Tufts University School of Medicine.

\section{REFERENCES}

1 National Academy of Sciences. The airliner cabin environment - air quality and safety. Washington, DC: National Academy Press, 1986.

2 US Dept. of Labor, Bureau of Labor Statistics, 2001 National Occupational Employment and Wage Estimates, 39-6031 Flight Attendants. $<$ www.bls.gov>

3 Nagda N, et al. Airliner cabin environment: contaminant measurements, health risks, and mitigation options U.S. Dept. of Transportation Report DOTP-15-89-5. Washington DC: US Department of Transport, 1989.

4 US Department of Health and Human Services. The health consequences of involuntary smoking. A report of the Surgeon General, 1986. Rockville, 
Maryland: Public Health Service, Centers for Disease Control, 1986. (DHHS Publication No (CDC) 87-8398.)

5 National Academy of Sciences. Environmental tobacco smoke -- measuring exposures and assessing health effects. Washington DC: National Academy Press, 1986.

6 Federal Register, Friday June 9, 2000. Part IV Department of Transportation Federal Aviation Administration 14 CFR Part 121, et al. Prohibition of Smoking on Scheduled Passenger Flights; Final Rules.

7 Space DR, Johnson RA, Rankin WL, et al. The airplane cabin environment: past, present, and future research. In: Nagda NL, ed. Air quality and comfort in airliner cabins, ASTM STP 1393. West Conshohocken, PA: American Society for Testing and Materials, 2000.

8 Duncan v. Northwest Airlines, Inc. Superior Court of Washington, No. 98-201158-1SEA. Class Action Complaint for Injunctive Relief, Medical Monitoring, and Damages.

9 Repace JL, Lowrey AH. Indoor air pollution, tobacco smoke, and public health. Science 1980;208:464-74.

10 US Environmental Protection Agency. Health effects of passive smoking: assessment of lung cancer in adults, and respiratory disorders in children. EPA/600/6-90/006F, December, 1992.

11 Hocking MB. Passenger aircraft cabin air quality: trends, effects, societal costs, proposals. Chemosphere 2000;41:603-15.

12 Arnold KE, Crha S, Patten L. The effect of recirculation on aircraft cabin air quality - in flight tests and simulation study. 2000. In: Nagda NL, ed. Air quality and comfort in airliner cabins, ASTM STP 1393. West Conshohocken, PA: American Society for Testing and Materials, 2000

13 Space DR. Cabin air quality. Airliner Magazine 1993 Oct-Dec: 19-24.

14 Martin GF. Northwest Airlines FLT OPS General Bulletin 93-49, Air quality and cabin comfort, 1993 August 13.

15 Lee SC, Poon CS, Li XD, et al. Air quality measurements on sixteen commercial aircraft. In: Nagda NL, ed. Air quality and comfort in airliner cabins, ASTM STP 1393. West Conshohocken, PA: American Society for Testing and Materials, 2000:45-60

16 O'Donnell A, Donnini G, Nguyen VH. Air quality, ventilation, temperature, and humidity in aircraff. ASHRAE Journal 1991 April:42-6.

17 Dumyahn TS, Spengler JD, Burge HA, et al. Comparison of the environments of transportation vehicles: results of two surveys. In: Nagda NL, ed. Air quality and comfort in airliner cabins, ASTM STP 1393. West Conshohocken, PA: American Society for Testing and Materials, 2000.

18 Pierce WM, Janczewski JN, Janczewski MG. Air quality on commercial aircraft. ASHRAE Journal 1999 Sept:26-33.

19 Nagda NL, Rector HE, Li Z, Space DR. Aircraft cabin air quality: a critical review of past monitoring studies. In: Nagda NL, ed. Air quality and comfort in airliner cabins, ASTM STP 1393. West Conshohocken, PA: American Society for Testing and Materials, 2000.

20 Daisey J. Tracers for assessing exposure to environmental tobacco smoke what are they tracing? Environmental Health Perspectives 1999;107(suppl 2):319-28.

21 Mattson ME, Boyd G, Byar C, et al. Passive smoking on commercial air flights. JAMA 1989;261:867-72.

22 Nagda N, Koontz MD, Konheim AG, et al. Measurement of cabin air quality aboard commercial airliners. Atmos Env 1992:26A:2203-10.

23 Waters MA, Bloom TF, Grajewski B, et al. Measurements of indoor air quality on commercial transport aircraft. Proceedings Indoor Air 2002: 9th International Conference on Indoor Air Quality and Climate, Monterey, California, 2002 June 30-July 5.

24 Lindgren T, Norbäck D, Andersson K, et al. Cabin environment and perception of cabin air quality among commercial aircrew. Aviation, Space and Environmental Medicine 2000;71:774-82.

25 Lindgren T, Norbäck D. Cabin air pollutants and climate in an aircraft with recirculated air on intercontinental flights. Proceedings Indoor Air 2002: 9th International Conference on Indoor Air Quality and Climate, Monterey, California, June 30-July 52002.

26 Lindgren T, Norbäck D. Cabin air quality: indoor pollutants and climate during intercontinental flights with and without tobacco smoking. Indoor Air 2002;12:263-72

27 Consolidated Safety Services, Inc. ASHRAE Research Project 957-RP, Final Report, Feb. 1999. Consolidated Safety Services, Inc. relate air quality and other factors to symptoms reported by passengers and crew on commercial transport category aircraft.

28 ASHRAE STANDARD 62-1973. Standards for natural and mechanical ventilation. The American Society of Heating, Refrigerating, and Air Conditioning Engineers, Inc. New York, 1973.
29 ASHRAE STANDARD 62-1999. Ventilation for acceptable indoor air quality. The American Society of Heating, Refrigerating, and Air Conditioning Engineers, Inc. Atlanta, 1999

30 Oldaker GB, Conrad FC. Estimation of effect of environmental tobacco smoke on air quality within passenger cabins of commercial aircraft. Environmental Science \& Technology 1987;21:994-9.

31 Malmfors T, Thorburn D, Westlin A. Air quality in passenger cabins of DC9 and MD80 aircraft. Environ Technol Lett 1989;10:613-28.

32 Eatough DE, Caka FM, Crawford J, et al. Environmental tobacco smoke in commercial aircraft. Atmospheric Environment 1992;26A:2211-8.

33 Crawford WA. Environmental tobacco smoke in airliners - health issues. Aerospace 1989 July:12-17.

34 Crawford WA, Holcomb LC. Environmental tobacco smoke (ETS) in airliners a health hazard evaluation. Aviation Space \& Environmental Medicine 1991;42:580-6.

35 Holcomb LC. Impact of environmental tobacco smoke on airline cabin air quality. Environmental Technology Letters 19988;9:509-14.

36 Repace JL, Lowrey AH. An enforceable indoor air quality standard for environmental tobacco smoke in the workplace." Risk Analysis 1993; 13:463-75

37 Repace JL, Jinot J, Bayard S, et al. Air nicotine and saliva cotinine as indicators of passive smoking exposure and risk. Risk Analysis 1998:18:71-83.

38 Pirkle JL, Flegal KM, Bernert JT, et al. Exposure of the population to environmental tobacco smoke: the third national health and nutrition examination survey, 1988 to 1991. JAMA 1996;275:1233-40.

39 ASHRAE STANDARD 62-1989. Ventilation for acceptable indoor air quality. The American Society of Heating, Refrigerating, and Air Conditioning Engineers, Inc. Atlanta, 1989.

40 Ott WR. Environmental statistics and data analysis. Boca Raton: Lewis Publishers, CRC Press, 1995

41 Jeft v. Philip Morris, et al. Circuit court, $11^{\text {th }}$ Judicial District, Miami-Dade County, Florida, General Jurisdiction Division, Case \# 00-01680-CA-22, Deposition of $G$. Routh.

42 McBride SJ. A marked point process model for the source proximity effect in the indoor environment. J Am Stat Assoc 2002;97:683-91.

43 McBride SJ, Ferro AR, OHt WR, et al. Investigations of the proximity effect for pollutants in the indoor environment. J Exposure Analysis \& Environmental Epidemiology 1999:602-21.

44 Pope CA, Dockery DW. Epidemiology of particle effects. In: Holgate ST, Samet JM, Koren HS, Maynard RL, eds. Air pollution and health. London: Academic Press, 1999

45 Federal Register: July 18, 1997 (Volume 62, Number 138)] [Rules and Regulations] [Page 38651-38701]

46 Junker MH, Danuser B, Monn C, et al. Acute sensory response of nonsmokers at very low environmental tobacco smoke concentrations in controlled laboratory settings. Environmental Health Perspectives 2001;109:1045-52.

47 Walker JC, Nelson PR, Cain WS, et al. Perceptual and psychophysiological responses of nonsmokers to a range of environmental tobacco smoke concentrations. Indoor Air 1997;7:173-88.

48 Janssen J. Ventilation for acceptable indoor air quality. ASHRAE Journal 1989 October:40-8.

49 Johnston JW. Letter from JW Johnston, CEO of RJ Reynolds Tobacco Co. Winston-Salem, NC to Secretary of Transportation F. Pena, Washington DC, July 191993.

50 Ehmann CW. Letter from Executive VP for R\&D, RJ Reynolds Tobacco, to Dr. WR Dowdle, Deputy Director, Center for Disease Control, July 191993.

51 Drake JW, Johnson DE. Measurements of certain environmental tobacco smoke components on long-range flights. Aviation, Space, and Environmental Medicine June 1990:531-42.

52 Guyton AC. Human physiology and mechanisms of disease, 5th ed. Philadelphia: WB Saunders, 1992

53 Repace JL, Lowrey AH. Risk assessment methodologies in passive smoking induced lung cancer. Risk Analysis 1990;10:27-37.

54 Klepeis NE, OHt WR, Switzer P. A multiple-smoker model for predicting indoor air quality in public lounges. Environmental Science and Technology 1996;30:2813-20.

55 Blissard L. Address to the Flight Aftendant Medical Research Institute Annual Meeting. Miami, FL, May 152003.

56 Speer $\mathbf{F}$. Tobacco and the nonsmoker. A study of subjective symptoms. Arch Environ Health 1968;16:443-6.

57 Savel H. Clinical hypersensitivity to cigarette smoke. Arch Environ Health 1970;21:146-8

58 National Research Council. The airliner cabin environment and the health of passengers and crew. Washington DC: NRC, National Academy Press, 2002. 